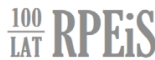

\section{LĄCZENIE STUDIÓW Z PRACĄ ZAROBKOWĄ A WEJŚCIE ABSOLWENTÓW WYŻSZYCH UCZELNI NA RYNEK PRACY}

\section{WPROWADZENIE}

Intuicja i literatura przedmiotu ${ }^{1}$ wskazuja, że praca zarobkowa - przed studiami lub w trakcie studiów - sprzyja uzyskaniu lepszej pozycji na rynku pracy po uzyskaniu dyplomu w stosunku do absolwentów bez takiego doświadczenia.

Badania podejmowane $\mathrm{w}$ Polsce wcześniej w tym zakresie prowadzone były na podstawie danych $\mathrm{z}$ wybranych uczelni i danych ankietowych. Od 2015 r. Ogólnopolski system monitorowania Ekonomicznych Losów Absolwentów szkół wyższych (dalej: „system ELA” lub „ELA”2) udostępnia dane o absolwentach pochodzace z systemu Zakładu Ubezpieczeń Społecznych, obejmujące blisko 96\% populacji osób, które uzyskały dyplom. Dzięki temu możliwe jest poszerzenie i pogłębienie analiz. Od 2019 r. dane te zawierają także informacje o pracy w ciagu roku przed rekrutacją na studia oraz podczas studiów, przy czym dotyczy to pracy na umowę o pracę lub samozatrudnienia. Osoby, które pracowały przed studiami lub podczas studiów, klasyfikowane sa jako posiadający „doświadczenie zawodowe absolwenci” ${ }^{3}$ niezależnie od czasu, jaki przepracowały. W systemie nie są dostępne dane o pracy na umowę zlecenie i umo-

" Marek Rocki, Szkoła Główna Handlowa w Warszawie, roma@sgh.waw.pl, https://orcid.org/0000-0001-9705-5726

1 Np. Richardson, Evans, Gbadamosi (2009); Săveanu, Ştefănescu (2012).

${ }^{2}$ ELA - ekonomiczne losy absolwentów, <www.ela.nauka.gov.pl>.

${ }^{3}$ Określenie „doświadczenie zawodowe absolwentów” występujące w opisie i raportach systemu ELA (zamiennie z „doświadczeniem pracy”, „doświadczeniem na rynku pracy”, „doświadczeniem pracy etatowej i samozatrudnienia przed uzyskaniem dyplomu”, „wcześniejszym doświadczeniem pracy etatowej lub samozatrudnienia") dotyczy osób, które przed uzyskaniem dyplomu miały doświadczenie: jakiejkolwiek pracy, pracy na umowę o pracę lub samozatrudnienia. W tekście niniejszego opracowania rozumiane jest jako doświadczenie pracy zarobkowej. Warto odnotować, że w literaturze występuje także w kontekście praktyk studenckich, por. Grobelna (2016). 
wę o dzieło, które były podpisane ze studentami do 26 roku życia. Oznacza to, że faktyczna liczba studentów pracujących w czasie studiów jest większa, niż wynika to z dalej prezentowanych analiz: wśród osób, które w systemie ELA sklasyfikowane sa jako nieposiadajace doświadczenia na rynku pracy są takie, które pracowały na podstawie umów o dzieło lub zlecenie. W konsekwencji wnioski wynikające z analiz są „niedoszacowane”: różnice pomiędzy sytuacja osób niepracujących zawodowo przed studiami i w trakcie studiów a pracujacymi mogą być w rzeczywistości większe.

Celem opracowania jest zbadanie, jak praca zawodowa przed studiami lub podczas studiów wpływa na sytuację absolwenta na rynku pracy (po ukończeniu studiów) w zestawieniu z osobami, które takich doświadczeń nie miały. Postawiono hipotezę, że osoby, które pracowały w roku poprzedzającym rekrutację na studia lub podczas studiów na podstawie umowy o pracę (lub były samozatrudnione), uzyskują wyższe wynagrodzenia i krócej szukają pracy po uzyskaniu dyplomu.

Prezentowane dalej analizy służace weryfikacji postawionej hipotezy dotyczą trybów, poziomów i grup kierunków ${ }^{4}$ studiów, w zależności bowiem od tych czynników różne są możliwości czasowe studentów (wynikające z intensywności studiów), motywacje, a także możliwości znalezienia pracy.

Analizowano dane dla pierwszego roku po uzyskaniu dyplomu dla osób, które ukończyły studia w roku $2018^{5}$.

\section{PRZEGLĄD LITERATURY}

Procesy tranzycji, czyli przechodzenia na rynek pracy absolwentów uczelni, badane są w wielu ośrodkach naukowych i z różnych punktów widzenia. W tym opracowaniu zwrócona zostanie uwaga na zwiąki zatrudnialności z doświadczeniem zawodowym, gdyż - jak wskazują liczni autorzy - jest ono jednym z istotnych czynników ułatwiających tranzycję.

Badania w zakresie tranzycji (zatrudnialności) wiążą się z teoriami poszukiwań na rynku pracy, teorią kapitału ludzkiego, a w kontekście absolwentów szkół wyższych - z teoriami rynku pracy: teorią dualnego rynku pracy ${ }^{6}$ (zakładająca, że rynek pracy jest podzielony na segmenty oferujące różne warunki pracy w zależności od wiedzy i doświadczenia), teorią filtra, w której wyższe wykształcenie jest zasadniczym czynnikiem dającym podstawy oceny szans (pozycji) na rynku pracy ${ }^{7}$, oraz teorią sygnalizacyjna, zgodnie z która opis „poziomu” edukacji potwierdzanej dyplomem jest „sygnałem” wysyłanym przez osobę poszukująca pracy do potencjalnych pracodawców ${ }^{8}$. Każda z tych teorii

\footnotetext{
${ }^{4}$ W sprawie definiowania kierunków studiów w kontekście systemu ELA por. Rocki (2018): 15.

${ }^{5}$ Dane dostępne w raportach ELA w lipcu 2020 r.

${ }^{6}$ Por. Kryńska (1995).

7 Arrow (1973).

8 Spence (1973).
} 
w inny sposób opisuje związki posiadanego wykształcenia z sytuacja absolwentów na rynku pracy, ale jak pisze Piróg99: „Najnowsze modele przechodzenia absolwentów uczelni wyższych odwołują się głównie do teorii kompetencji i teorii kapitału ludzkiego". Przyjmuje się tu, że posiadanie dyplomu połączone z doświadczeniem zawodowym jest „sygnałem” poprawiającym obraz absolwenta.

$\mathrm{Na}$ rolę doświadczenia wskazują m.in. Andrews i Higson ${ }^{10}$, relacjonując badania z czterech krajów europejskich. Doświadczenie zawodowe (w tym praktyki podczas studiów), ale także m.in. jakość programów oceniana post factum przez absolwentów była przedmiotem analiz w projekcie HEGESCO obejmującym także Polskę ${ }^{11}$.

Okay-Somerville i Scholarios ${ }^{12}$, pisząc o absolwentach uczelni brytyjskich, podkreślaja, że w przypadku osób wchodzących na rynek pracy doświadczenie zawodowe, eksploracja możliwości rozwoju karier, mentorzy i networking uznawane są za zachowania proaktywne (zawierające się w CSM - carrier self-management) i definiowane jako postawy ważne w uplasowaniu się na odpowiedniej pozycji wśród kandydatów konkurujących o stanowiska wymagające wysokich umiejętności oraz że: „Doświadczenie zawodowe uznaje się za czynnik korzystny w poszukiwaniu pracy i osiaganiu sukcesów zawodowych"13.

W Polsce badania w tym zakresie nie maja długiej tradycji, ponieważ do początku lat dziewięćdziesiątych absolwenci byli bez problemów absorbowani przez rynek pracy ${ }^{14}$. Analizy w tym zakresie prowadzone były incydentalnie przez uczelnie zainteresowane doskonaleniem ofert dydaktycznych i wiążące taki kierunek rozwoju z badaniami naukowymi. Przykładowo, Jarecki15 omawia wyniki badań przeprowadzonych wśród studentów V roku kierunków ekonomicznych Uniwersytetu Szczecińskiego: „większość (64\%) studentów zarządzania i marketingu oraz informatyki i ekonometrii uzyskuje dochody z pracy własnej”. Podobne wyniki badań z Uniwersytetu Ekonomicznego w Katowicach prezentuje Ostoj ${ }^{16}$. Wyników takich nie można oczywiście uogólniać i przenosić na studentów innych kierunków i innych uczelni. Wyniki dotyczące grupy kierunków studiów STEM (Science, Technology, Engineering and Mathematics) i wykorzystujące dane z systemu ELA omawiają Zając, Jasiński, Bożykowski ${ }^{17}$, wskazując, że istnieje zróżnicowanie losów absolwentów w tej grupie. Interesujace są relacje z badań porównujących Polskę i Hiszpa-

9 Piróg (2013): 156.

10 Andrews, Higson (2008).

11 Badania ankietowe, objęły absolwentów rocznika 2003 w pięć lat po uzyskaniu dyplomu. Polska znalazła się wśród trzech krajów o najniższym - zdaniem absolwentów - dopasowaniu uzyskanego wykształcenia do wykonywanej pracy (Allen, Velde 2009: wykres 3.12).

12 Okay-Somerville, Scholarios (2015): 38.

13 Okay-Somerville, Scholarios (2015): 41.

14 Piróg (2013a): 132.

15 Jarecki (2010).

16 Ostoj (2018).

17 Zając, Jasiński, Bożykowski (2017). 
nię ${ }^{18}$, przedstawiające sytuację w Słowenii ${ }^{19} \mathrm{i}$ w badaniu przekrojowym kilka państw europejskich ${ }^{20}$.

Wyniki badań przekrojowych prezentuje też raport Instytutu Pracy i Spraw Socjalnych ${ }^{21}$. Jak stwierdzono, $44 \%$ badanej populacji absolwentów nie szukało pracy, ponieważ pracowało już podczas studiów ${ }^{22}$. Jednocześnie stwierdzono, że aż $46 \%$ absolwentów zmuszonych było do podjęcia pracy w innym zawodzie niż wyuczony, gdyż wybrany przez nich kierunek nie był zgodny z potrzebami rynku pracy.

Jak pisze Marszałek ${ }^{23}$ : „Z roku na rok zwiększa się liczba studentów (tych na studiach stacjonarnych) decydujących się na podjęcie w trakcie nauki pracy zarobkowej. Argumentują to nie tylko chęcią podreperowania studenckiego budżetu, ale często możliwością zdobycia tak pożądanego doświadczenia zawodowego". Podobne wnioski wyciaga ze swych badań Ostoj ${ }^{24}$.

Wyniki badań wykorzystujacych „Monitoring rynku pracy” (Bilans Kapitału Ludzkiego 2012), w których analizowano sytuację zawodową 1500 absolwentów ${ }^{25}$, wskazują na zróżnicowane losy absolwentów różnych stopni studiów i zróżnicowanych „klas” absolwentów, podkreślając rolę doświadczenia zawodowego.

Z drugiej jednak strony, po pierwsze - jak zauważa Lindberg ${ }^{26}$ - niebezpieczeństwo tkwi w tym, że studenci (absolwenci) mogą nie dostrzegać swych silnych stron wnikających z posiadania doświadczenia z pracy podczas studiów, a po drugie - jak pisze Hesketh ${ }^{27}$ - wymagania pracodawców wyraźnie się zmieniaja. Zwracają na to uwagę także Brown, Hesketh i Williams ${ }^{28}$, stwierdzając, że zatrudnialność może też być postrzegana jako cecha rynku pracy, a nie tylko skutek uzyskanego przez absolwentów wykształcenia i ich cech indywidualnych.

Dane administracyjne prezentowane w systemie ELA uniemożliwiaja pomiar kapitału tranzycyjnego, ale mogą być wykorzystane do wzbogacenia analiz przeprowadzanych klasycznymi metodami ankietowymi. Jednocześnie ich szczegółowość pozwala na wyciaganie wniosków na innym stopniu agregacji, niż te, które wynikały z badań ankietowych.

Informacje udostępniane przez system ELA potwierdzają intuicyjne opinie o pozytywnym wpływie pracy podczas studiów na zwiększenie szans na szybkie

18 Czubak-Koch et al. (2017).

19 Kosi et al. (2013).

20 Teichler (2002).

${ }^{21}$ Raport (2012): 20.

${ }^{22} \mathrm{~W}$ badaniach wykorzystano ankiety zebrane metody CAWI wśród 48 uczelni, 597 pracodawców i 10732 studentów i absolwentów. Jak podano: „[...] jedynie dwie uczelnie (Szkoła Główna Handlowa i Politechnika Łódzka) zostały ocenione przez wymaganą liczbę studentów i absolwentów”.

${ }^{23}$ Marszałek (2012): 23.

${ }^{24}$ Ostoj (2016): 235.

25 Dziechciarz-Duda, Przybysz (2014).

${ }^{26}$ Lindberg (2008): 383.

27 Hesketh (2010).

28 Brown, Hesketh, Williams (2002): 9. 
znalezienie dobrze wynagradzanej pracy, zawierając jednocześnie informacje o odstępstwach od takiego stanu rzeczy. Oczywiście, jak piszą Zając, Jasiński i Bożykowski ${ }^{29}$, oceniając na podstawie danych ELA wpływ uprzedniego zatrudnienia na poszukiwanie pracy po studiach (może ono oznaczać faktyczne poszukiwanie pracy lub kontynuację pracy podjętej podczas studiów), trzeba jednak wziąć pod uwagę to, że dane te obejmuja jednie pracę w roku poprzedzającym rekrutację na studia.

\section{METODA BADAWCZA I ŹRÓDLO DANYCH}

Podstawą analiz wykorzystujących jako metodę badawczą ${ }^{30}$ metodę obserwacyjną oraz metodę badania dokumentów, jakimi są dane administracyjne z systemu ELA są dane tworzone na podstawie rejestrów Zakładu Ubezpieczeń Społecznych oraz z rejestrów POL-on. Najmniejszą jednostką w systemie ELA jest grupa absolwentów ${ }^{31}$, dla której wyodrębniono numer w systemie POL-on, co oznacza, że studia stacjonarne i studia niestacjonarne prowadzone przez dana jednostkę szkoły wyższej na danym kierunku studiów są zarejestrowane odrębnie.

Spośród wskaźników dostępnych w systemie ELA do zweryfikowania hipotezy badawczej wybrano charakterystyki opisujące losy absolwentów na rynku pracy, którymi są względny wskaźnik bezrobocia (WWB) oraz względny wskaźnik zarobków (WWZ).

WWB obliczany jest w systemie ELA w następujacy sposób: dla każdego absolwenta wyznacza się relację jego indywidualnego ryzyka bezrobocia do średniej rejestrowanego bezrobocia w powiecie zamieszkania w okresie objętym badaniem. Wartość wskaźnika prezentowanego w raportach ELA jest równa średniej z tych proporcji. Ryzyko bezrobocia w systemie ELA zdefiniowane jest jako średni procent liczby miesięcy po miesiącu uzyskania dyplomu, w których absolwenci byli zarejestrowani jako bezrobotni. Wartości WWB mniejsze niż 1 oznaczaja, że przeciętnie ryzyko bezrobocia wśród absolwentów jest niższe niż stopa bezrobocia w ich powiatach zamieszkania, a wartości powyżej 1 oznaczaja, że przeciętnie ryzyko bezrobocia wśród absolwentów jest wyższe niż stopa bezrobocia w ich powiatach zamieszkania;

Z kolei WWZ obliczany jest w następujący sposób: dla każdego absolwenta wyznaczona zostaje relacja jego średnich zarobków do średnich zarobków w powiecie (powiatach) jego zamieszkania w okresie objętym badaniem. Wartość wskaźnika umieszczanego w raportach ELA jest równa średniej z tych

${ }^{29}$ Zając, Jasiński, Bożykowski (2018): 199; badania dotyczyły osób, które uzyskały dyplom w roku 2014.

30 Por. Apanowicz (2002).

31 W systemie ELA grupy takie nazywane sa „kierunek”, co jest mylące, gdyż określenie „kierunek” odnosi się do programu studiów określonego efektami uczenia się oraz opisu procesu prowadzącego do ich uzyskania. 
proporcji. Wartości większe niż 1 oznaczają że przeciętnie absolwenci zarabiają powyżej średniej wynagrodzeń w powiatach ich zamieszkania, natomiast wartości poniżej 1 oznaczaja, że przeciętnie absolwenci zarabiają poniżej średniej wynagrodzeń w powiatach ich zamieszkania.

Ścisłe definicje i sposób obliczania WWB i WWZ podane są w opisie systemu ELA ${ }^{32}$. Tutaj zauważmy jedynie, że WWB i WWZ w sposób syntetyczny charakteryzuja losy absolwentów, ponieważ niezależnie od miejsca pracy (zamieszkania) wskazują one na przygotowanie absolwentów do podjęcia pracy oraz ich rynkową wycenę przez pracodawców. Krótki czas poszukiwania pracy po uzyskaniu dyplomu i wysokie wynagrodzenia oznaczaja, że uczelnia oferuje i realizuje programy studiów zgodne z zapotrzebowaniem rynku pracy. Pośrednio oznacza to także, że uczelnia skutecznie współpracuje z pracodawcami nad doskonaleniem programów studiów oraz prowadzi badania naukowe sprzyjajace takiemu doskonaleniu. Do pewnego stopnia można przyjać, że $\mathrm{WWB}^{33} \mathrm{i}$ WWZ z punktu widzenia wejścia absolwentów na rynek pracy syntetycznie charakteryzuja jakość działań uczelni.

W systemie ELA podawane są informacje o wartościach WWB i WWZ z wyodrębnieniem grup osób, które pracowały zarobkowo w roku poprzedzającym rekrutację na studia, grup osób, które pracowały podczas studiów oraz grup osób, które nie mają takich doświadczeń. W toku prac wartości wskaźników dla poszczególnych grup zostały zagregowane tak, by obliczyć wartości WWB i WWZ dla wyodrębnionych podgrup według poziomu i trybu studiów oraz dziedzin nauki, do których uczelnie przyporządkowały kierunki studiów. Zatem obliczenia polegały na mnożeniu wartości wskaźników dla poszczególnych grup przez liczebność tych grup, zsumowaniu tak uzyskanych liczb zgodnie z przyjętym kryterium agregacji (np. dla danego poziomu i trybu studiów), a następnie podzieleniu tak uzyskanej sumy przez łączną liczbę absolwentów zagregowanych grup.

Należy dodać, że dane zawarte w systemie ELA muszą być analizowane przy wzięciu pod uwagę następujących ograniczeń, które mogą mieć wpływ na wyniki analiz:

- w zbiorach ZUS nie sa rejestrowane umowy o dzieło, umowy zlecenia podpisywane ze studentami do 26 roku życia, umowy zawierane za granica Polski oraz praca bez umowy. Dane moga także nie obejmować ubezpieczonych w KRUS, a więc dane o absolwentach w systemie ELA nie obejmuja wszelkich możliwych form pracy. Informacją określająca wiarogodność wnioskowania jest udział absolwentów zarejestrowanych w ZUS;

${ }^{32}$ Materiały informacyjne na temat zasobów udostępnianych w ramach szóstej edycji ogólnopolskiego systemu monitorowania Ekonomicznych Losów Absolwentów szkół wyższych (ELA), <https://ela.nauka.gov.pl/pl/experts/source-data> [dostęp: 27.08.2021].

${ }^{33}$ Trzeba bowiem pamiętać, że doświadczenie bezrobocia w systemie ELA definiowane jest jako procent absolwentów, którzy kiedykolwiek w badanym okresie byli zarejestrowani jako bezrobotni. Takie zarejestrowanie może jednak oznaczać zarówno poszukiwanie pracy, jak i odroczenie decyzji o podjęciu pracy w związku z chęcią wykorzystania systemu pomocy społecznej, por. Rocki, Werner (2021): 8. 
- dane ZUS nie zawieraja informacji o wykonywanym zawodzie. Nie wiadomo więc, czy praca przed studiami, podczas nich i po uzyskaniu dyplomu ma zwiąek z kierunkiem studiów;

- dla zachowania anonimowości raporty i dane źródłowe prezentowane w systemie ELA dotycza grup absolwentów liczących co najmniej 10 osób. Nie są także podawane wyniki dla podgrup liczacych mniej niż 3 osoby. Takie sytuacje dotyczą także grup obejmujących osoby, które nie podjęły pracy po studiach, a jako takie klasyfikowane są także osoby, które poszukiwały pracy ponad 12 miesięcy.

\section{DANE PODSTAWOWE DOTYCZĄCE ROCZNIKA 2018}

Rocznik 2018 to 6869 grup absolwentów liczących łącznie 315561 osób. Wśród tych grup jest wiele o małym udziale absolwentów zarejestrowanych w ZUS. Przyjęto, że nie będą analizowane grupy, w których udział osób zarejestrowanych w ZUS jest mniejszy niż $60 \%^{34}$. Analizy dotyczą wobec tego 4312 grup liczących 242599 osób, z których 89,75\% jest zarejestrowanych w ZUS ${ }^{35}$, dla których dostępne są informacje o WWB i WWZ.

Strukturę badanych grup absolwentów według stopni i trybów studiów oraz dziedzin nauki, do których przyporządkowano kierunki studiów prezentuje tabela 1. Struktura ta (wynikająca z liczebności poszczególnych grup) ma wpływ na interpretację podawanych dalej wskaźników. Przykładowo, inaczej interpretuje się przeciętne ryzyko bezrobocia absolwenta ${ }^{36}$ równe 1,31 dla grupy liczącej 838 osób, które uzyskały dyplom na kierunkach przyporządkowanych do dziedziny nauk chemicznych niż ryzyko bezrobocia równe 1,33 dla grupy 20280 absolwentów kierunków przyporządkowanych do nauk technicznych.

Prawie połowę absolwentów badanego rocznika stanowią absolwenci kierunków technicznych i ekonomicznych I i II stopnia (tab. 1). Wśród absolwentów jednolitych studiów magisterskich ponad połowę stanowią absolwenci kierunków prawnych (ale jednocześnie aż 59,75\% absolwentów kierunków prawnych kończyło studia I lub II stopnia, głównie w trybie niestacjonarnym) oraz medycznych.

${ }^{34}$ Niski udział absolwentów w ZUS może wynikać z tego, że studentami byli obcokrajowcy (w szczególności na kierunkach prowadzonych w języku angielskim). Przykładowo: z liczącej 111 osób grupy absolwentów kierunku lekarskiego Uniwersytetu Medycznego w Białymstoku żadna nie jest zarejestrowana w ZUS; spośród 103 absolwentów zarządzania (studia niestacjonarne II stopnia) w Wyższej Szkole Menedżerskiej w Warszawie tylko 6\%, a spośród 137 absolwentów stosunków międzynarodowych (studia stacjonarne I stopnia) Krakowskiej Akademii A.F. Modrzewskiego w ZUS zarejestrowanych jest 26, tj. 19\%.

${ }^{35}$ Liczebność badanych grup stanowi 79,55\% absolwentów rocznika 2018, dla których system ELA podaje informacje.

${ }^{36}$ Podane są wartości względnych wskaźników bezrobocia (WWB). 
Potencjalny związek z pracą zawodową i doświadczenie w tym zakresie (niekoniecznie związane z kierunkiem studiów) powinni mieć studenci studiów niestacjonarnych, stanowiący $28,25 \%$ ogółu absolwentów analizowanego rocznika. Ten tryb studiów, po pierwsze, skierowany jest do osób pracujących, a po drugie, ich organizacja pozwala na łączenie studiów z pracą ${ }^{37}$. Jak się jednak okazuje, zgodnie z danymi z systemu ELA, liczba osób, które w badanych grupach rocznika 2018 pracowały zawodowo przed studiami lub podczas studiów, wynosi 106 927, co stanowi 44,08\% absolwentów. W tej liczbie jest 61647 osób, które pracowały w roku poprzedzającym studia, oraz 45280 osób mających doświadczenie zawodowe uzyskane w czasie studiów.

Szczegółową strukturę absolwentów, którzy pracowali przed studiami lub w ich trakcie, wg stopnia, trybu studiów i dziedziny nauki prezentuje tabela 2. Najmniejszy udział w grupie osób, które pracowały zawodowo przed studiami lub podczas studiów dotyczy absolwentów studiów stacjonarnych I stopnia (25,33\% tej grupy) i stacjonarnych studiów jednolitych magisterskich (odpowiednio 19,15\%). Przed studiami pracowały głównie osoby, które otrzymały dyplom na studiach niestacjonarnych II stopnia $(66,93 \% \mathrm{z}$ tej grupy), natomiast praca podczas studiów związana jest $\mathrm{z}$ absolwentami niestacjonarnych jednolitych studiów magisterskich $(42,61 \%)$.

\section{WYNIKI BADAŃ}

\section{Względny wskaźnik bezrobocia}

Wartości WWB dla absolwentów, którzy pracowali przed studiami lub podczas nich oraz tych, którzy nie mieli takich doświadczeń przedstawiono w tabeli 3.

Dla osób bez doświadczenia pracy w przypadku studiów I stopnia wartości wskaźnika WWB dla absolwentów studiów niestacjonarnych są dwu-trzykrotnie większe niż dla studiów stacjonarnych. Ogółem dla I stopnia studiów WWB dla „niedoświadczonych” absolwentów studiów stacjonarnych rocznika 2018 wyniósł 0,49 , a dla niestacjonarnych $-1,22$. Poza kierunkami związanymi z dziedziną nauk rolniczych i nauk o kulturze fizycznej i obszarem sztuki wartości WWB dla tej kategorii absolwentów są wyższe niż 1 . W przypadku studiów II stopnia WWB dla praktycznie wszystkich grup niedoświadczonych absolwentów są wyższe niż 1 , a w kilku przypadkach wyższe niż 2 . Inaczej niż w przypadku studiów I stopnia dla absolwentów niemających doświadczenia pracy zawodowej wartości WWB dla pewnych grup kierunków są wyższe dla osób po studiach stacjonarnych (np. nauki o ziemi: 1,75 studia stacjonarne, 0,75 studia niestacjonarne, rolnicze odpowiednio: 1,98 i 1,01, a farmaceutycz-

${ }^{37}$ Definicja studiów stacjonarnych z ustawy prawo o szkolnictwie wyższym (art. 63): forma studiów wyższych, w ramach których co najmniej połowa punktów ECTS objętych programem studiów jest uzyskiwana w ramach zajęć z bezpośrednim udziałem nauczycieli akademickich lub innych osób prowadzących zajęcia i studentów. 
ne 2,13 i 0,9), a dla innych wyższe są dla osób po studiach niestacjonarnych (np. biologiczne: studia stacjonarne 1,54, a studia niestacjonarne 2,86).

Biorąc pod uwagę dziedziny, do których przyporządkowano kierunki studiów, najbardziej odczuli bezrobocie niemający doświadczenia w pracy zawodowej absolwenci weterynarii (WWB równe prawie 4) i kierunków prawnych (głównie II stopnia, gdzie WWB przekracza 2). Także w przypadku osób mających doświadczenie zawodowe absolwenci niestacjonarnych studiów I stopnia (poza dwoma wyjątkami: kierunki z zakresu nauk o ziemi i nauk chemicznych) byli bardziej narażeni na bezrobocie niż absolwenci studiów stacjonarnych.

Ogólna wartość WWB dla absolwentów bez doświadczenia zawodowego wyniosła 0,96 i jest większa od wartości dla absolwentów wcześniej pracujących $(0,56)$, co wskazuje na znacząca, pozytywną rolę doświadczenia pracy. Jednie w przypadku kierunków biologicznych i rolniczych na studiach stacjonarnych I stopnia, kierunków leśnych na studiach stacjonarnych II stopnia oraz kierunków farmaceutycznych na studiach jednolitych magisterskich niestacjonarnych WWB osób doświadczonych jest wyższy niż dla niedoświadczonych. Tak więc w większości przypadków - jak wskazują tabele 4 i 5 - doświadczenie zawodowe znacząco zmniejsza ryzyko bezrobocia mierzone WWB. Co więcej, dla absolwentów studiów niestacjonarnych bez doświadczenia pracy (poza studiami I stopnia w dziedzinie nauk o zdrowiu i w obszarze sztuki) WWB przekracza 1 (absolwenci ci byli w roku po uzyskaniu dyplomu bardziej doświadczeni bezrobociem niż przeciętnie w powiatach ich zamieszkania), co w przypadku osób z doświadczeniem zawodowym występuje jednie w dwu przypadkach (studia farmaceutyczne I stopnia i biologiczne II stopnia).

Istotne zróżnicowanie występuje między grupami absolwentów według dziedzin nauk. Dla absolwentów studiów II stopnia zagrożenie bezrobociem absolwentów kierunków ekonomicznych, matematycznych, fizycznych, medycznych czy o zdrowiu jest niższe niż przeciętne.

\section{Względny wskaźnik zarobków}

Tabela 4 zawiera zestawienia wartości względnego wskaźnika zarobków dla absolwentów nieposiadających i posiadających doświadczenie zawodowe odpowiednio dla absolwentów studiów stacjonarnych i studiów niestacjonarnych oraz wyodrębnionych grup kierunków. Można zauważyć, że WWZ dla osób bez doświadczenia pracy nie różnią się znacząco, biorąc pod uwagę tryb studiów, ale w przypadku studiów I stopnia WWZ absolwentów studiów stacjonarnych w większości przypadków jest mniejsze niż dla studiów niestacjonarnych, podczas gdy w przypadku studiów II stopnia jest odwrotnie.

Wartości WWZ wskazuja, że we wszystkich przypadkach grupy absolwentów, którzy pracowali przed studiami lub podczas nich uzyskały w roku po zakończeniu studiów przeciętne wynagrodzenie wyższe niż grupy osób bez takiego doświadczenia. Porównując wartości WWZ osób z doświadczeniem zawodowym i bez niego można też zauważyć, że w kilku przypadkach (kierunki związane z naukami matematycznymi, technicznymi, leśnymi, farmaceutycznymi) absolwenci z doświadczeniem zawodowym w roku po uzyskaniu 
dyplomu uzyskali wynagrodzenia wyższe niż przeciętne w miejscach swojego zamieszkania, podczas gdy takich wynagrodzeń nie uzyskały - poza jednym wyjątkiem nauk farmaceutycznych, studia niestacjonarne, jednolite magisterskie - grupy bez doświadczenia pracy.

Warto odnotować, że grupy absolwentów mających doświadczenie pracy zawodowej kierunków przyporządkowanych do dziedzin nauk ekonomicznych, matematycznych, technicznych, medycznych i nauk o zdrowiu uzyskały przeciętne wynagrodzenie wyższe niż absolwenci kierunków humanistycznych społecznych, prawnych i farmaceutycznych.

\section{Odstępstwa od reguły}

Jak wskazują analizy, prawie 16\% absolwentów (38 196 osób, 804 grupy ze 196 uczelni) należy do podgrup osób, które mając doświadczenie zawodowe, uzyskały przeciętne wartości WWB wyższe o co najmniej 0,25 pkt niż podgrupy osób bez takiego doświadczenia, a które otrzymały dyplom na tym samym kierunku (w tej samej grupie charakteryzowanej numerem POL-on). Takie grupy wskazują na istnienie dodatkowych czynników powodujących, że osoby z doświadczeniem pracy zawodowej w pewnych przypadkach wypadają na rynku pracy gorzej niż osoby bez takiego doświadczenia. Może to sugerować, że doświadczenie zawodowe tej grupy absolwentów studiów stacjonarnych nie było związane z kończonymi studiami.

W liczbach bezwzględnych większość takich przypadków stanowią absolwenci studiów stacjonarnych I stopnia (45,3\%) oraz II stopnia (21,6\%). Biorąc pod uwagę dziedziny nauki największe grupy stanowią absolwenci kierunków technicznych $(25,69 \%)$, ekonomicznych $(15,47 \%)$ i społecznych $(12,15 \%)$, co związane jest $\mathrm{z}$ dużym udziałem absolwentów kierunków przyporządkowanych do tych dziedzin nauki w ogólnej ich liczbie. W relacji do liczby absolwentów danego poziomu i trybu studiów oraz dziedziny, do której przyporządkowano kierunek studiów, najczęściej sytuacja taka dotyczyła absolwentów niestacjonarnych studiów I stopnia ${ }^{38}$ kierunków rolniczych i farmaceutycznych.

Analizy szczegółowe wskazuja, że największe różnice między WWB absolwentów mających doświadczenie pracy zawodowej przed uzyskaniem dyplomu a absolwentami bez takiego doświadczenia dotyczą grup mało licznych (10-40 osób) ${ }^{39}$. Przykładowo:

- dla mających doświadczenie pracy zawodowej absolwentów studiów stacjonarnych II stopnia kierunku architektura wnętrz (3 osoby w grupie 20 osobowej) Uniwersytetu Artystycznego w Poznaniu względny wskaźnik bezrobocia wyniósł 8,45 , podczas gdy osoby niemające doświadczenia pracy charakteryzuje wskaźnik równy 3,32 ;

38 Pomijając absolwentów niestacjonarnych jednolitych studiów magisterskich kierunków związanych z naukami teologicznymi, którzy stanowią 0,026\% absolwentów rocznika 2018.

39 Jak podano w Rocki (2020): 845, tab. 3, w grupach o liczebności od 10 do 50 osób jest 65\% absolwentów rocznika 2014, co sugeruje, że dla rocznika 2018 jest podobnie. 
- w przypadku politologii (studia stacjonarne II stopnia, Uniwersytet Adama Mickiewicza) wartość WWB dla osób mających doświadczenie zawodowe (połowa z 30 absolwentów) wyniosła 6,32, a dla niedoświadczonych - 1,57;

- dziesięcioro absolwentów polityki społecznej Uniwersytetu Warszawskiego (studia stacjonarne I stopnia) pomimo doświadczenia pracy ma WWB równe 4,15, podczas gdy 18 osób bez doświadczenia pracy praktycznie nie doświadczyło bezrobocia (WWB równe 0,08).

Przegląd kierunków studiów, dla których absolwenci z doświadczeniem pracy zawodowej w większym stopniu doświadczyli bezrobocia, wskazuje, że wśród grup 156 „nazw” kierunków są:

- w ok. 30 przypadkach kierunki o nazwach sugerujących wąski zakres efektów kształcenia (pasujacy bardziej do specjalności), jak na przykład: publikowanie cyfrowe i sieciowe (Uniwersytet Wrocławski), sztuka ogrodowa (Uniwersytet Rolniczy w Krakowie), komunikacja promocyjna i kryzysowa (Uniwersytet Śląski), hipologia i jeździectwo (Uniwersytet Przyrodniczy w Lublinie);

- kierunki „popularne” prowadzone przez uczelnie, dla których dziedzina nauki związana z takimi kierunkami nie jest kanoniczna. Przykładowo: kulturoznawstwo na AGH, pielęgniarstwo w Akademii Humanistyczno-Ekonomicznej w Łodzi, filologia na Politechnice Koszalińskiej, ekonomia oraz turystyka i rekreacja na Politechnice Opolskiej, turystyka i rekreacja na Uniwersytecie Pedagogicznym w Krakowie, pedagogika w Wyższej Szkole Bankowej w Gdańsku, dietetyka oraz kosmetologia w Wyższej Szkole Informatyki i Zarządzania w Rzeszowie. Łącznie odnotować można 50 takich przypadków wśród 196 uczelni.

W przypadku WWZ różnic przekraczajacych 0,25 pkt na niekorzyść absolwentów z doświadczeniem pracy zawodowej jest znacząco mniej: tylko 184 osoby. Przypadki, w których udział osób z takim doświadczeniem był znaczący, to przykładowo:

- logistyka, studia stacjonarne I stopnia w PWSZ w Lesznie, gdzie 11 osób z doświadczeniem (44\% absolwentów) uzyskało wynagrodzenia dające wartość WWZ równą 0,46 , podczas gdy dla osób bez takiego doświadczenia jest to 0,78 ;

- 11 absolwentów informatyki z Uniwersytetu Wrocławskiego (stacjonarne, I stopnia) mających doświadczenie zawodowe charakteryzuje WWZ równe 1,32, a 20 osób bez doświadczenia ma WWZ równe 1,62;

- 55,56\% (15 osób) absolwentów informatyki i ekonometrii (stacjonarne, II stopnia) z AGH mających doświadczenie pracy ma WWZ równe 0,98 , a osoby bez doświadczenia pracy zawodowej 1,26.

Wspomniane przypadki odstępstwa od reguły mówiącej o pozytywnym wpływie doświadczenia pracy na wynagrodzenia i unikanie bezrobocia nie pozwalają na wyciagnięcie wniosków ogólnych ze względu na uwzględnienie $\mathrm{w}$ analizie jedynie jednego rocznika absolwentów. Wskazują one zapewne na indywidualne cechy zarówno programu, trybu i poziomu studiów, jak i trybu rekrutacji. Do sformułowania ogólnych wniosków w tych przypadkach potrzebne będzie powtórzenie analiz dla kolejnych roczników absolwentów. 


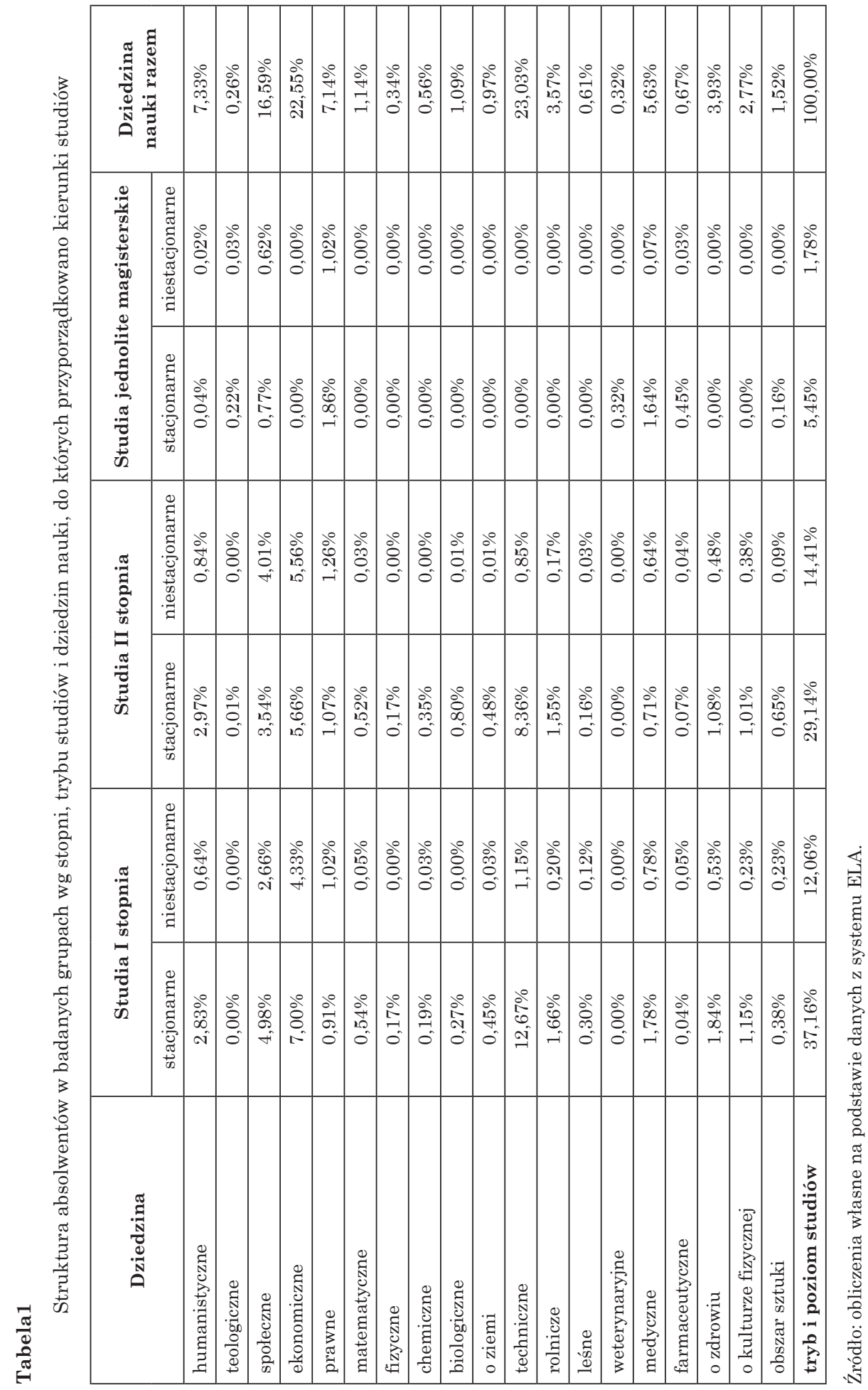




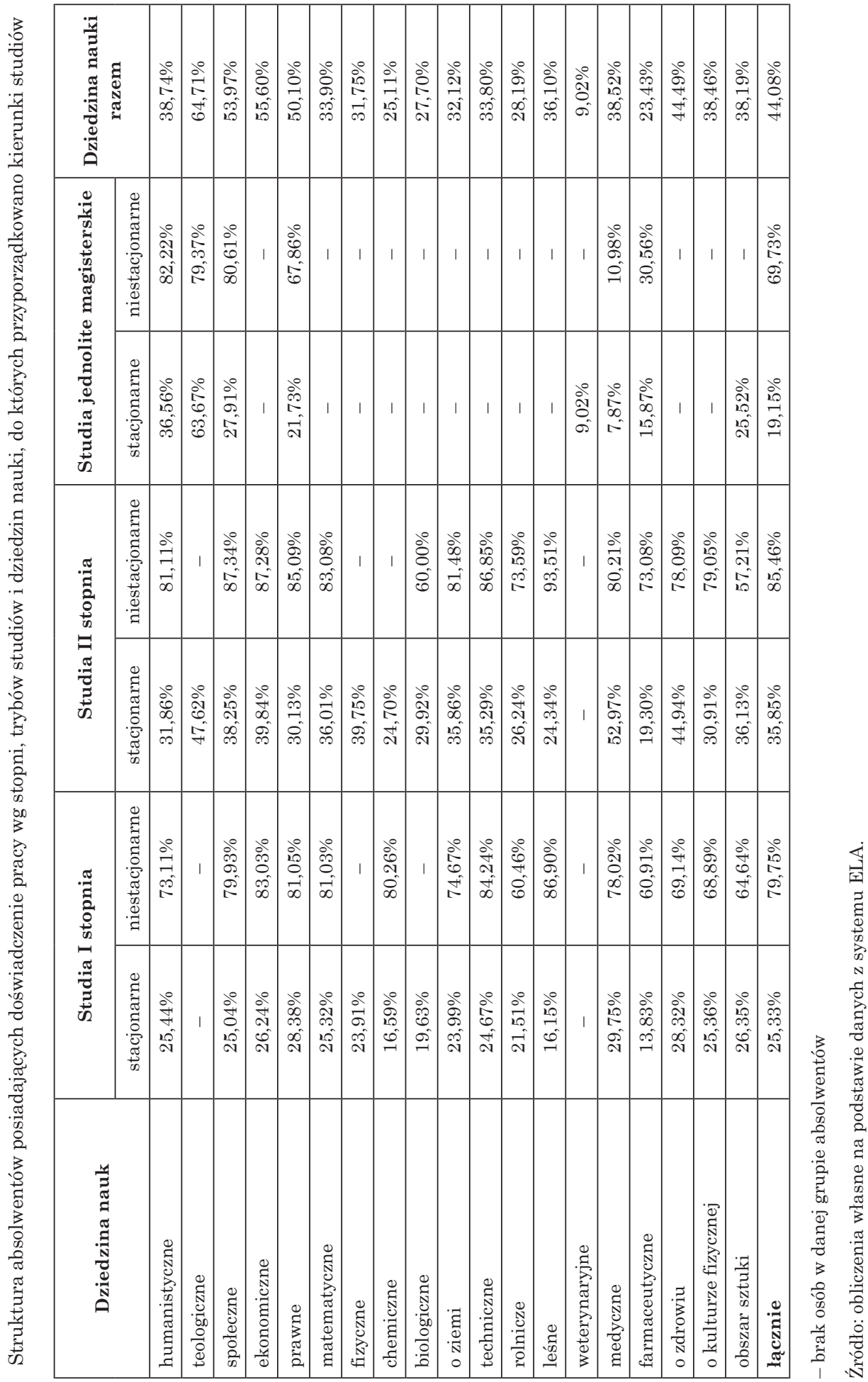




\begin{tabular}{|c|c|c|c|c|c|c|c|c|c|c|c|c|c|c|c|c|c|c|c|c|c|}
\hline$\frac{.0}{\frac{\pi}{n}}$ & 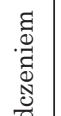 & 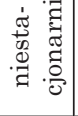 & $\begin{array}{l}10 \\
\stackrel{2}{0} \\
0\end{array}$ & $\begin{array}{l}10 \\
\stackrel{2}{0} \\
0\end{array}$ & $\begin{array}{l}+ \\
\infty \\
0 \\
0\end{array}$ & 1 & $\begin{array}{l}8 \\
8 \\
0\end{array}$ & 1 & 1 & 1 & 1 & 1 & 1 & 1 & 1 & 1 & $\begin{array}{l}8 \\
\vdots\end{array}$ & $\begin{array}{c}0 \\
\vdots \\
\vdots \\
0 \\
0\end{array}$ & & & 1 \\
\hline 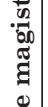 & $\begin{array}{l}3 \\
3 \\
0 \\
0 \\
0 \\
N\end{array}$ & 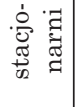 & $\begin{array}{l}0 \\
0 \\
0 \\
0\end{array}$ & $\begin{array}{l}0 \\
\stackrel{-}{0} \\
0\end{array}$ & $\begin{array}{l}\vec{\sigma} \\
0\end{array}$ & 1 & $\begin{array}{l}10 \\
8 \\
0 \\
0\end{array}$ & 1 & 1 & 1 & 1 & 1 & 1 & 1 & 1 & $\begin{array}{l}\infty \\
\infty \\
\text { o }\end{array}$ & $\begin{array}{l}\mathcal{1} \\
\stackrel{2}{0}\end{array}$ & 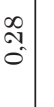 & & 1 & $\begin{array}{l}8 \\
0 \\
0\end{array}$ \\
\hline 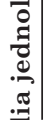 & 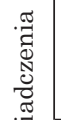 & 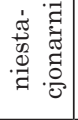 & $\begin{array}{c}8 \\
0 \\
\text { i }\end{array}$ & $\begin{array}{l}19 \\
\text { If } \\
0\end{array}$ & $\left|\begin{array}{l}\infty \\
\infty \\
-1\end{array}\right|$ & 1 & $\begin{array}{l}\infty \\
\infty \\
-1\end{array}$ & 1 & 1 & 1 & 1 & 1 & 1 & 1 & 1 & 1 & $\begin{array}{l}\vec{J} \\
\tilde{O}^{\prime}\end{array}$ & 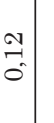 & & 1 & 1 \\
\hline$\frac{B}{0}$ & 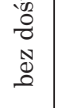 & 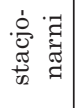 & $\begin{array}{l}\stackrel{10}{+} \\
\rightarrow \\
\rightarrow\end{array}$ & $\begin{array}{l}\infty \\
+ \\
0 \\
0\end{array}$ & $\begin{array}{l}\infty \\
= \\
=\end{array}$ & 1 & \begin{tabular}{l}
8 \\
\hdashline \\
-1
\end{tabular} & 1 & 1 & 1 & 1 & 1 & 1 & 1 & 1 & $\begin{array}{l}\mathscr{8} \\
\infty^{\circ}\end{array}$ & $\begin{array}{l}\infty \\
-1 \\
0\end{array}$ & $\begin{array}{c}0 \\
0 \\
0 \\
0\end{array}$ & & 1 & \begin{tabular}{l|}
$\circ$ \\
o. \\
iv
\end{tabular} \\
\hline \multirow{4}{*}{ 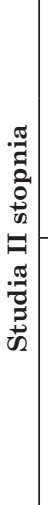 } & 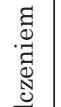 & 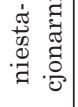 & 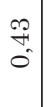 & 1 & $\begin{array}{l}10 \\
10 \\
0 \\
0\end{array}$ & 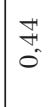 & $\begin{array}{l}\overrightarrow{6} \\
0 \\
0\end{array}$ & $\begin{array}{l}8 \\
0\end{array}$ & 1 & 1 & $\begin{array}{l}\mathscr{8} \\
-i\end{array}$ & $\begin{array}{c}0 \\
0 \\
0 \\
0\end{array}$ & $\begin{array}{l}29 \\
9 \\
0\end{array}$ & $\mid \begin{array}{c}3 \\
10 \\
0\end{array}$ & $\begin{array}{l}18 \\
0 \\
0\end{array}$ & 1 & $\begin{array}{c}10 \\
0 \\
0\end{array}$ & $\begin{array}{l}2 \\
2 \\
0\end{array}$ & 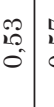 & \begin{tabular}{l|l}
5 & \\
0 & 0 \\
0 & 0
\end{tabular} & $\begin{array}{l}+ \\
\infty \\
0 \\
0 \\
0\end{array}$ \\
\hline & 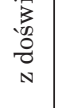 & 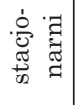 & $\begin{array}{l}\mathscr{8} \\
0 \\
0\end{array}$ & $\begin{array}{l}8 \\
0\end{array}$ & 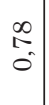 & $\begin{array}{l}\text { î } \\
\text { î } \\
0\end{array}$ & $\begin{array}{l}1 \\
\infty \\
0 \\
0\end{array}$ & 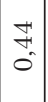 & $\begin{array}{l}\infty \\
\stackrel{1}{ } \\
0\end{array}$ & $\begin{array}{l}\overrightarrow{6} \\
0\end{array}$ & $\begin{array}{l}\infty \\
0 \\
0 \\
0\end{array}$ & $\begin{array}{l}+ \\
\sigma_{0}^{\prime} \\
0\end{array}$ & $\begin{array}{l}10 \\
0^{\circ} \\
0\end{array}$ & $\begin{array}{l}\stackrel{2}{-} \\
\Rightarrow\end{array}$ & $\begin{array}{l}0 \\
-1 \\
-1\end{array}$ & 1 & $\begin{array}{l}0 \\
0 \\
0 \\
0\end{array}$ & \begin{tabular}{ll}
$\infty$ & \\
\multirow{2}{*}{} & \\
- &
\end{tabular} & 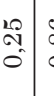 & \begin{tabular}{l|l}
$\infty$ & \\
$\infty$ & \\
0 & 1
\end{tabular} & $\begin{array}{l}3 \\
0 \\
-1 \\
-1\end{array}$ \\
\hline & 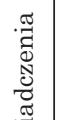 & 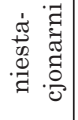 & $\overrightarrow{0}$ & 1 & $\begin{array}{l}\stackrel{5}{\Sigma} \\
-\end{array}$ & 우 & $\begin{array}{l}\overrightarrow{0} \\
\hat{v}\end{array}$ & $\left|\begin{array}{c}\infty \\
10 \\
0 \\
\sim\end{array}\right|$ & 1 & 1 & \begin{tabular}{l}
$\infty$ \\
$\infty$ \\
\multirow{v}{*}{}
\end{tabular} & $\begin{array}{l}10 \\
0 \\
0\end{array}$ & $\begin{array}{l}\infty \\
\stackrel{\infty}{\sim} \\
-1\end{array}$ & $\begin{array}{c}\overrightarrow{0} \\
- \\
-1\end{array}$ & $\mid \begin{array}{c}\stackrel{\mathscr{I}}{+} \\
- \\
-1\end{array}$ & 1 & 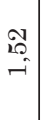 & $\begin{array}{l}8 \\
\sigma_{0}\end{array}$ & 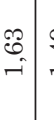 & \begin{tabular}{l|l}
$\stackrel{P}{\rightarrow}$ \\
$\rightarrow$
\end{tabular} & \begin{tabular}{c|}
8 \\
8 \\
i
\end{tabular} \\
\hline & $\begin{array}{l}0 \\
0 \\
0 \\
0 \\
0 \\
0 \\
0\end{array}$ & 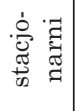 & 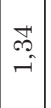 & $\begin{array}{l}\text { 尺े } \\
\text { ๓) }\end{array}$ & $\mid \begin{array}{l}2 \\
\stackrel{8}{0} \\
-1\end{array}$ & $\underset{r}{\stackrel{H}{-}}$ & $\begin{array}{l}0 \\
\infty \\
0 \\
0\end{array}$ & $\mid \begin{array}{l}\infty \\
-1 \\
-1\end{array}$ & $\begin{array}{l}\mathscr{R} \\
\dot{\sigma} \\
0\end{array}$ & $\vec{\omega}$ & $\begin{array}{l}+1 \\
-10 \\
-1\end{array}$ & $\begin{array}{l}\stackrel{10}{5} \\
\Rightarrow \\
-7\end{array}$ & $\begin{array}{l}\infty \\
\stackrel{\leftrightarrow}{-} \\
-\end{array}$ & $\begin{array}{l}\infty \\
\stackrel{\infty}{-} \\
-\end{array}$ & $\begin{array}{l}0 \\
- \\
-1\end{array}$ & 1 & 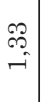 & \begin{tabular}{l|l}
$\infty$ & \\
$\vec{N}$ &
\end{tabular} & \begin{tabular}{l|l}
\multirow{2}{N}{} & , \\
- &
\end{tabular} & 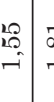 & $\begin{array}{l}\vec{\infty} \\
-\mathfrak{r}\end{array}$ \\
\hline \multirow{4}{*}{ 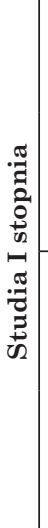 } & 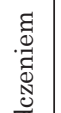 & 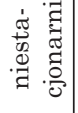 & $\begin{array}{l}0 \\
0 \\
0 \\
0\end{array}$ & 1 & $\begin{array}{c}10 \\
2 \\
0\end{array}$ & \begin{tabular}{|l|l}
$\infty$ \\
10 \\
0 \\
0
\end{tabular} & $\begin{array}{l}\overrightarrow{6} \\
0\end{array}$ & $\mid \begin{array}{l}1 \\
10 \\
0 \\
0\end{array}$ & 1 & $\begin{array}{l}0 \\
0 \\
0 \\
0\end{array}$ & 1 & 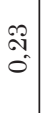 & $\begin{array}{c}\infty \\
\stackrel{1}{1} \\
0\end{array}$ & $\begin{array}{c}-1 \\
0 \\
0\end{array} \mid$ & $\begin{array}{l}0 \\
10 \\
0 \\
0\end{array}$ & 1 & $\begin{array}{l}8 \\
8 \\
0\end{array}$ & 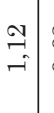 & $\begin{array}{l}0 \\
0 \\
0 \\
0\end{array}$ & \begin{tabular}{l|l}
-1 & $a$ \\
0 \\
0
\end{tabular} & $\begin{array}{l}\vec{\sigma} \\
\dot{0}\end{array}$ \\
\hline & 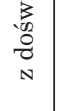 & 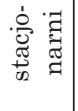 & $\begin{array}{l}0 \\
\stackrel{1}{1} \\
0\end{array}$ & 1 & $\begin{array}{l}0 \\
+1 \\
0\end{array}$ & $\begin{array}{l}0 \\
\text { 우 } \\
0\end{array}$ & \begin{tabular}{|l}
$\infty$ \\
$\cong$ \\
0 \\
0
\end{tabular} & $\begin{array}{l}n \\
-1 \\
0\end{array}$ & $\begin{array}{l}28 \\
0 \\
0\end{array}$ & $\begin{array}{l}10 \\
\infty \\
0 \\
0 \\
0\end{array}$ & $\begin{array}{l}0 \\
\tilde{m} \\
0 \\
0\end{array}$ & $\begin{array}{l}0 \\
0 \\
0 \\
0\end{array}$ & $\begin{array}{l}\infty \\
0 \\
0 \\
0\end{array}$ & $\mid \begin{array}{l}0 \\
0 \\
0 \\
0\end{array}$ & $\left|\begin{array}{c}-1 \\
0 \\
0\end{array}\right|$ & 1 & $\begin{array}{l}0 \\
+ \\
0\end{array}$ & 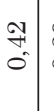 & 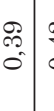 & \begin{tabular}{c|c}
\multirow{2}{*}{} & 8 \\
0 & 1
\end{tabular} & $\begin{array}{l}0 \\
2 \\
0 \\
0\end{array}$ \\
\hline & 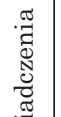 & 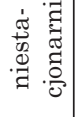 & $\begin{array}{c}\stackrel{\gamma}{0} \\
-i \\
-\end{array}$ & 1 & 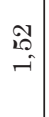 & $\underset{\sim}{0}$ & $\mid \begin{array}{l}\vec{N} \\
-\end{array}$ & $\begin{array}{l}\overrightarrow{2} \\
0 \\
0\end{array} \mid$ & 1 & 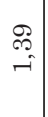 & & $\begin{array}{l}\mathscr{D} \\
- \\
-\end{array}$ & $\begin{array}{l}\stackrel{H}{\sim} \\
\stackrel{-}{-}\end{array}$ & $\left|\begin{array}{c}1 \\
\infty \\
0 \\
0\end{array}\right|$ & $\left|\begin{array}{c}0 \\
0 \\
-1 \\
-1\end{array}\right|$ & 1 & $\begin{array}{l}10 \\
-10 \\
-1\end{array}$ & $\begin{array}{l}\text { Na } \\
- \\
-1\end{array}$ & \begin{tabular}{c|c}
$\underset{\mathcal{F}}{\rightarrow}$ & $\vdots$ \\
$\rightarrow$ &
\end{tabular} & \begin{tabular}{l|l}
0 & \\
$\infty$ & \\
0 & \\
0
\end{tabular} & $\begin{array}{l}+1 \\
\infty \\
0 \\
0\end{array}$ \\
\hline & $\begin{array}{l}w_{2} \\
0 \\
0 \\
0 \\
0 \\
0\end{array}$ & 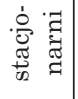 & $\begin{array}{l}-1 \\
0 \\
0\end{array}$ & 1 & $\left|\begin{array}{l}10 \\
20 \\
0 \\
0\end{array}\right|$ & $\begin{array}{l}10 \\
+1 \\
0\end{array}$ & $\begin{array}{l}\tilde{6} \\
0 \\
0\end{array}$ & $\mid \begin{array}{c}\mathfrak{m} \\
\stackrel{9}{+} \\
0\end{array}$ & $\begin{array}{l}8 \\
0 \\
0\end{array}$ & $\begin{array}{l}0 \\
⿱ 1 \\
0\end{array}$ & $\begin{array}{l}10 \\
0 \\
0\end{array}$ & $\begin{array}{l}0 \\
1 \\
0\end{array}$ & $\begin{array}{c}10 \\
+1 \\
0\end{array}$ & 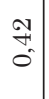 & $\begin{array}{l}8 \\
0 \\
0 \\
0\end{array}$ & 1 & $\begin{array}{l}\infty \\
+ \\
0 \\
0\end{array}$ & \begin{tabular}{l|}
8 \\
0 \\
0
\end{tabular} & \begin{tabular}{l|l}
8 & 1 \\
0 & \\
0 & 2
\end{tabular} & \begin{tabular}{l|l}
10 & \\
0 & 0 \\
0 &
\end{tabular} & 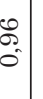 \\
\hline & 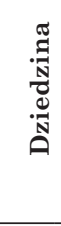 & & 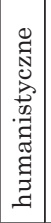 & 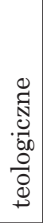 & 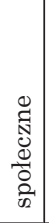 & 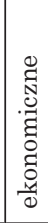 & 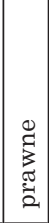 & 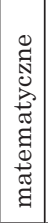 & 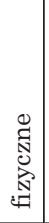 & 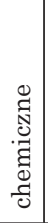 & 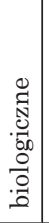 & $\begin{array}{l}\cdot \vec{d} \\
\cdot \stackrel{N}{N} \\
0\end{array}$ & 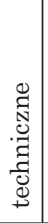 & 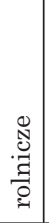 & 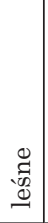 & 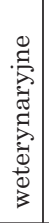 & 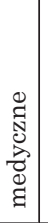 & 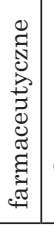 & 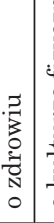 & 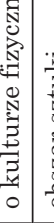 & 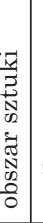 \\
\hline
\end{tabular}




\begin{tabular}{|c|c|c|c|c|c|c|c|c|c|c|c|c|c|c|c|c|c|c|c|c|c|c|}
\hline$\frac{0}{\frac{n}{n}}$ & 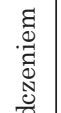 & 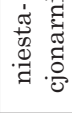 & $\begin{array}{l}\mathbb{N} \\
\mathbb{N} \\
0\end{array}$ & $\begin{array}{l}-\infty \\
\infty \\
0 \\
0\end{array}$ & 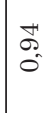 & 1 & $\begin{array}{l}\infty \\
\infty \\
0 \\
0\end{array}$ & 1 & 1 & 1 & 1 & 1 & 1 & 1 & 1 & 1 & $\mid \begin{array}{c}10 \\
10 \\
0 \\
0\end{array}$ & $\begin{array}{ll}28 \\
0 \\
-1\end{array}$ & 1 & 1 & 1 & $\begin{array}{l}\infty \\
\infty \\
0\end{array}$ \\
\hline 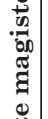 & $\begin{array}{l}5 \\
5 \\
0 \\
0 \\
0 \\
N\end{array}$ & 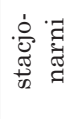 & $\begin{array}{l}+1 \\
0 \\
0\end{array}$ & $\begin{array}{l}8 \\
0 \\
0 \\
0\end{array}$ & 둥 & 1 & $\begin{array}{l}\infty \\
0 \\
0 \\
0\end{array}$ & 1 & 1 & 1 & 1 & 1 & 1 & 1 & 1 & $\mid \begin{array}{l}10 \\
10 \\
0 \\
0\end{array}$ & $\begin{array}{l}R \\
0 \\
0\end{array}$ & $\begin{array}{l}\mathcal{O} \\
- \\
-i\end{array}$ & 1 & 1 & $\begin{array}{l}\mathscr{3} \\
0 \\
0 \\
0\end{array}$ & 둥 \\
\hline 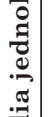 & 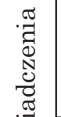 & 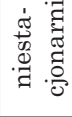 & 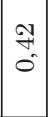 & $\mid$\begin{tabular}{c|}
$-\overrightarrow{0}$ \\
0 \\
0
\end{tabular} & 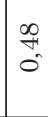 & 1 & 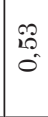 & 1 & 1 & 1 & 1 & 1 & 1 & 1 & 1 & 1 & 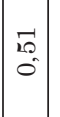 & 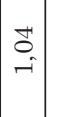 & 1 & 1 & 1 & $\begin{array}{l}\text { : } \\
10 \\
0\end{array}$ \\
\hline$\vec{b}$ & $\begin{array}{l}\text { wn } \\
0 \\
0 \\
0 \\
0 \\
0\end{array}$ & 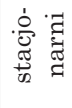 & 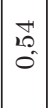 & $\begin{array}{l}0 \\
0 \\
0 \\
0\end{array}$ & $\begin{array}{l}10 \\
0 \\
0\end{array}$ & 1 & 每 & 1 & 1 & 1 & 1 & 1 & 1 & 1 & 1 & 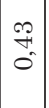 & $\mid \begin{array}{l}2 \\
10 \\
0 \\
0\end{array}$ & $\begin{array}{l}0 \\
\mathscr{S} \\
0 \\
0\end{array}$ & 1 & 1 & $\begin{array}{l}0 \\
\infty \\
0 \\
0\end{array}$ & $\begin{array}{l}\infty \\
\infty \\
0 \\
0 \\
0\end{array}$ \\
\hline & 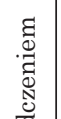 & 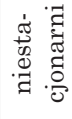 & $\begin{array}{l}\infty \\
\infty \\
0 \\
0\end{array}$ & 1 & $\begin{array}{l}\mathscr{R} \\
0 \\
0\end{array}$ & $\begin{array}{l}\mathscr{8} \\
0 \\
0\end{array}$ & $\begin{array}{l}\infty \\
\infty \\
0\end{array}$ & $\begin{array}{l}\infty \\
\infty \\
-1 \\
-1\end{array}$ & 1 & 1 & $\begin{array}{l}1 \\
0 \\
0\end{array}$ & $\begin{array}{l} \pm \\
0 \\
0\end{array}$ & $\begin{array}{l}+ \\
0 \\
-1\end{array}$ & $\mid \begin{array}{l}10 \\
\infty \\
0 \\
0\end{array}$ & $\begin{array}{c}8 \\
8 \\
-1\end{array}$ & 1 & $\begin{array}{l}E \\
0 \\
0\end{array}$ & $\mid \begin{array}{l}10 \\
10 \\
0 \\
0\end{array}$ & $\begin{array}{l}0 \\
0 \\
0\end{array}$ & $\begin{array}{l}\stackrel{0}{1} \\
0\end{array}$ & $\begin{array}{l}\Re \\
\stackrel{0}{0} \\
0\end{array}$ & $\begin{array}{c}1 \\
\infty \\
0 \\
0\end{array}$ \\
\hline 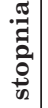 & 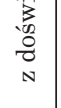 & 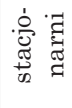 & $\begin{array}{l}E \\
0 \\
0\end{array}$ & $\begin{array}{l}\overrightarrow{6} \\
0 \\
0\end{array}$ & ㅍ & $\vec{\sigma}$ & \begin{tabular}{|l}
18 \\
8 \\
0
\end{tabular} & $\mid \begin{array}{l}0 \\
\stackrel{N}{N} \\
-7\end{array}$ & $\mid \begin{array}{l}8 \\
8 \\
-7\end{array}$ & $\begin{array}{l}1 \\
0 \\
0\end{array}$ & $\begin{array}{l}R \\
0 \\
0\end{array}$ & $\begin{array}{l}E \\
0 \\
0\end{array}$ & $\mid \begin{array}{c}0 \\
0 \\
-1\end{array}$ & $\mid \begin{array}{l}18 \\
0 \\
0\end{array}$ & $\begin{array}{l}8 \\
\infty \\
0\end{array}$ & 1 & $\mid \begin{array}{l}0 \\
\mathscr{2} \\
0 \\
0\end{array}$ & $\mid$ & $\begin{array}{l}\mathscr{\infty} \\
\tilde{\sigma} \\
0\end{array}$ & $\begin{array}{l}0.0 \\
0 \\
0\end{array}$ & \begin{tabular}{l|}
0 \\
0 \\
0
\end{tabular} & 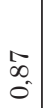 \\
\hline $\begin{array}{l}\frac{\pi}{3} \\
\frac{\pi}{3} \\
\frac{D}{2}\end{array}$ & 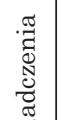 & 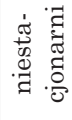 & 荈 & 1 & $\begin{array}{l}0 \\
10 \\
0\end{array}$ & \begin{tabular}{|l}
$\infty$ \\
10 \\
0 \\
0
\end{tabular} & 疍 & $\begin{array}{l}-1 \\
0 \\
0\end{array}$ & 1 & 1 & $\begin{array}{l}0 \\
\stackrel{1}{1} \\
0\end{array}$ & $\mid \begin{array}{l}20 \\
0 \\
0\end{array}$ & $\begin{array}{l}0 \\
0 \\
0 \\
0\end{array}$ & $\mid \begin{array}{c}0 \\
1 \\
10 \\
0 \\
0\end{array}$ & $\mid \begin{array}{l}10 \\
0 \\
0 \\
0\end{array}$ & 1 & $\mid \begin{array}{l}0 \\
10 \\
0 \\
0\end{array}$ & $\begin{array}{c}\infty \\
\infty \\
0 \\
0\end{array}$ & $\begin{array}{l}\text { r } \\
\text { O }\end{array}$ & 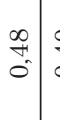 & \begin{tabular}{l|} 
연 \\
ㄴ.
\end{tabular} & $\begin{array}{l}\overbrace{0} \\
\text { i⿱⺈ } \\
0\end{array}$ \\
\hline & $\begin{array}{l}\text { ?n } \\
0 \\
\text { N } \\
0 \\
0\end{array}$ & 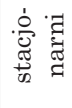 & $\begin{array}{c}10 \\
10 \\
0 \\
0\end{array}$ & \begin{tabular}{|l|l}
$\infty$ \\
+ \\
0 \\
0
\end{tabular} & $\begin{array}{l}50 \\
0 \\
0\end{array}$ & $\begin{array}{l}\overline{6} \\
0 \\
0\end{array}$ & 年 & $\mid \begin{array}{l}\infty \\
1 \\
0 \\
0\end{array}$ & \begin{tabular}{|l|}
18 \\
0 \\
0 \\
0
\end{tabular} & $\mid \begin{array}{l}0 \\
1 \\
0 \\
0\end{array}$ & $\begin{array}{l}8 \\
10 \\
0\end{array}$ & $\begin{array}{l}0 \\
i 0 \\
0 \\
0 \\
0\end{array}$ & 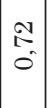 & $\mid \begin{array}{l}0 \\
10 \\
0 \\
0 \\
0\end{array}$ & $\begin{array}{l}\infty \\
0 \\
0 \\
0\end{array}$ & 1 & $\begin{array}{l}10 \\
10 \\
0\end{array}$ & $\begin{array}{c}7 \\
\vdots \\
0\end{array}$ & $\begin{array}{l}10 \\
0 \\
0\end{array}$ & $\begin{array}{c}\infty \\
+ \\
+ \\
0\end{array}$ & \begin{tabular}{l}
$\vec{F}$ \\
\multirow{2}{0}{} \\
0
\end{tabular} & $\begin{array}{l}8 \\
0 \\
0\end{array}$ \\
\hline & 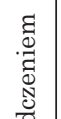 & 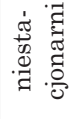 & $\begin{array}{l} \pm \\
0 \\
0\end{array}$ & 1 & E & $\begin{array}{l}+1 \\
\infty \\
0 \\
0\end{array}$ & \begin{tabular}{|l}
12 \\
0 \\
0
\end{tabular} & $\begin{array}{l}0 \\
-1 \\
-1\end{array}$ & 1 & $\begin{array}{l}\infty \\
\infty \\
0\end{array}$ & 1 & $\begin{array}{l}2 \\
\mathbb{1} \\
0\end{array}$ & $\begin{array}{l}8 \\
-1 \\
-1\end{array}$ & $\begin{array}{l}尺 \\
0 \\
0\end{array}$ & $\stackrel{\vec{H}}{\stackrel{-}{二}}$ & 1 & $\begin{array}{l}0 \\
0 \\
0\end{array}$ & $\mid \begin{array}{l}1 \\
0 \\
0 \\
0\end{array}$ & $\begin{array}{l}8 \\
0 \\
0\end{array}$ & 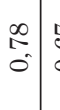 & $\begin{array}{l}\hat{0} \\
0\end{array}$ & $\begin{array}{l}\overrightarrow{1} \\
0 \\
0\end{array}$ \\
\hline 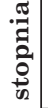 & $\begin{array}{l}3 \\
3 \\
0 \\
8 \\
-8 \\
N\end{array}$ & 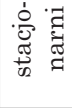 & $\begin{array}{l}\infty \\
10 \\
10 \\
0\end{array}$ & 1 & $\begin{array}{l}\text { LI } \\
0 \\
0\end{array}$ & '] & \begin{tabular}{|l}
$\mathcal{1}$ \\
0 \\
0 \\
0
\end{tabular} & $\mid \begin{array}{l}\overrightarrow{0} \\
- \\
-1\end{array}$ & $\begin{array}{l}8 \\
\infty \\
0 \\
0\end{array}$ & $\mid \begin{array}{c}0 \\
10 \\
0 \\
0\end{array}$ & 우 & $\mid \begin{array}{l}N \\
i 0 \\
0 \\
0\end{array}$ & 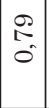 & $\mid \begin{array}{c}\mathscr{g} \\
\stackrel{1}{1} \\
0\end{array}$ & $\begin{array}{l}\Omega \\
10 \\
0 \\
0\end{array}$ & 1 & $\begin{array}{c}10 \\
5 \\
0\end{array}$ & $\begin{array}{c}10 \\
+1 \\
0 \\
0\end{array}$ & 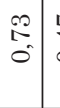 & 今. & 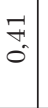 & $\begin{array}{l}\widehat{0} \\
0 \\
0\end{array}$ \\
\hline 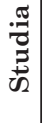 & 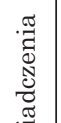 & 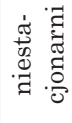 & $\begin{array}{l}\not \\
\dot{4} \\
0\end{array}$ & 1 & $\begin{array}{l}\text { क } \\
\text { + }\end{array}$ & 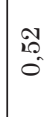 & \begin{tabular}{l}
$\stackrel{2}{0}$ \\
\hdashline \\
0
\end{tabular} & $\mid$\begin{tabular}{c}
9 \\
\multirow{1}{*}{} \\
0
\end{tabular} & 1 & $\begin{array}{l}5 \\
0 \\
0\end{array}$ & 1 & $\mid \begin{array}{l}0 \\
10 \\
0 \\
0\end{array}$ & $\mid \begin{array}{l}0 \\
0 \\
0 \\
0\end{array}$ & $\mid \begin{array}{l}2 \\
\stackrel{9}{*} \\
0 \\
0\end{array}$ & $\begin{array}{l}0 \\
0 \\
0 \\
0\end{array}$ & 1 & $\begin{array}{c}m \\
\stackrel{+}{+} \\
0\end{array}$ & $\mid$ & $\begin{array}{c}5 \\
0 \\
0 \\
0\end{array}$ & $\begin{array}{c}0 \\
+1 \\
0\end{array}$ & $\begin{array}{l}\text { 연 } \\
\text { ○ }\end{array}$ & \begin{tabular}{l}
$\infty$ \\
\multirow{+}{*}{} \\
0
\end{tabular} \\
\hline & $\begin{array}{l}0 \\
0 \\
0 \\
0 \\
0\end{array}$ & 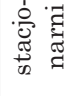 & $\begin{array}{l}\sharp \\
\sharp \\
0 \\
0\end{array}$ & 1 & 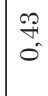 & $\begin{array}{l}\infty \\
+ \\
+ \\
0\end{array}$ & $\begin{array}{l}\text { 우 } \\
0 \\
0\end{array}$ & $\begin{array}{l}0 \\
0 \\
0 \\
0\end{array}$ & $\begin{array}{l}1 \\
0 \\
0 \\
0\end{array}$ & $\begin{array}{l}\mathfrak{y} \\
\text { - } \\
0\end{array}$ & $\begin{array}{l}1 \\
0 \\
0 \\
0\end{array}$ & $\begin{array}{l}0 \\
0 \\
0 \\
0\end{array}$ & $\mid \begin{array}{c}\infty \\
0 \\
0 \\
0 \\
0\end{array}$ & $\begin{array}{l}F \\
\dot{0} \\
0\end{array}$ & $\mid \begin{array}{l}1 \\
10 \\
0 \\
0 \\
0\end{array}$ & 1 & $\mid \begin{array}{l}\infty \\
10 \\
0 \\
0\end{array}$ & 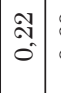 & $\begin{array}{l}8 \\
0 \\
0\end{array}$ & $\begin{array}{l}0 \\
0 \\
0 \\
0\end{array}$ & $\begin{array}{c}20 \\
0 \\
0 \\
0 \\
0\end{array}$ & $\begin{array}{c}-10 \\
0 \\
0\end{array}$ \\
\hline & 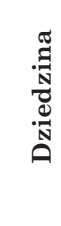 & & 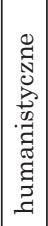 & 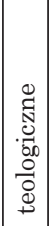 & 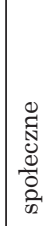 & 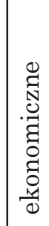 & 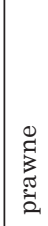 & 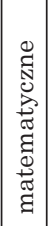 & 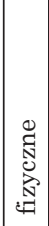 & 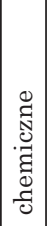 & 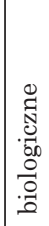 & 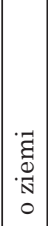 & 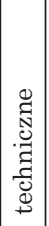 & 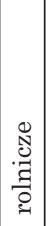 & 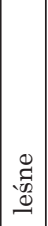 & 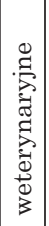 & 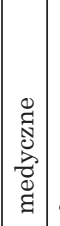 & 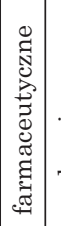 & 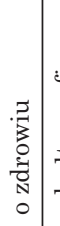 & 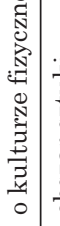 & 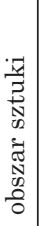 & $\begin{array}{c} \\
\frac{0}{00} \\
\frac{0}{0} \\
0\end{array}$ \\
\hline
\end{tabular}




\section{PODSUMOWANIE}

Podsumowując rozważania, należy przypomnieć, że w systemie ELA nie są dostępne dane o pracy na umowę zlecenie i umowę dzieło, które były zawierane ze studentami do 26 roku życia, co oznacza, że liczba studentów pracujących w czasie studiów jest większa, niż wynika to z analiz. Wobec tego wśród osób, które w systemie ELA sklasyfikowane są jako nieposiadające „doświadczenia pracy", sa pracujacy podczas studiów na podstawie umowy o dzieło lub zlecenie, a to oznacza, że różnice pomiędzy sytuacją osób niepracujących zawodowo w trakcie studiów a pracującymi mogą być w rzeczywistości większe.

Analiza danych dla rocznika 2018 potwierdziła pozytywną rolę doświadczenia pracy w procesie tranzycji absolwentów na rynek pracy. Zestawienie wartości wskaźników syntetycznych WWB i WWZ wskazuje na lepszą sytuację osób mających doświadczenie pracy zawodowej zarówno ze względu na uzyskiwane zarobki, jak i na zagrożenie bezrobociem. Z zestawień wynika też, że wyższe wynagrodzenia uzyskują absolwenci studiów niestacjonarnych. Może to być argumentem przemawiajacym za kształceniem w takim trybie: studenci moga pracować, uzyskując niezbędne środki finansowe i doświadczenie zawodowe, pracodawcy dzięki studentom uzyskują nieformalną możliwość transferu wiedzy bezpośrednio z uczelni, a uczelnia zyskuje kontakt z rzeczywistymi problemami gospodarki i społeczeństwa. Wyższe wynagrodzenia tej grupy absolwentów mogą wynikać zarówno z tego, że pomimo problemów związanych z łączeniem pracy ze studiami, pracodawcy doceniają ambicje edukacyjne, jak i z tego, że absolwenci studiów niestacjonarnych posiadają dłuższy staż pracy. Może to także oznaczać, że pracodawcy uważaja, że kompetencje uzyskiwane w toku studiów sa zbyt ogólne, a praca podczas studiów je „wzbogaca”. Brak w systemie ELA informacji o wykonywanym zawodzie nie umożliwia jednak prowadzenia szczegółowych analiz w tym zakresie. Można przypuszczać, że w przypadku najwyższych różnic między wartościami WWB a WWZ dla badanych grup absolwentów, praca studentów - przeciętnie rzecz biorąc - była związana z praca podjęta po uzyskaniu dyplomu. Świadczyć o tym może to, że najlepsze z punktu widzenia tranzycji na rynek pracy wartości wskaźników dotyczą kierunków przyporządkowanych do dziedzin nauk ekonomicznych, matematycznych, technicznych, medycznych i o zdrowiu ${ }^{40}$.

Podsumowując wyniki analiz, należy wskazać, że w pewnych przypadkach wcześniejsze doświadczenie pracy zawodowej nie sprzyjało tranzycji na rynek pracy. Dotyczyło to w szczególności absolwentów kierunków o nazwach sugerujących waski zakres efektów kształcenia oraz kierunków prowadzonych przez uczelnie, dla których dziedzina nauki, do której przyporządkowano kierunek, nie jest związana z jej zasadniczą misja.

Jak wskazują badania omówione w przeglądzie literatury, także studenci uważaja że praca podczas studiów sprzyja znalezieniu odpowiedniego zatrudnienia, ale jest także formą weryfikacji poprawności wyboru kierunku stu-

${ }^{40}$ Por. Rocki (2019): 352. 
diów. Trzeba jednak podkreślić, że często łączenie pracy ze studiami prowadzi do problemów z wypełnianiem obowiązków studenckich i przedłużania czasu koniecznego na uzyskanie dyplomu, o czym świadczą pojawiajace się w systemie ELA dane dotyczące grup, które otrzymały dyplom w większej niż planowana liczbie semestrów ${ }^{41}$. Czasami prowadzi to do rezygnacji $\mathrm{z}$ formalnego kończenia studiów. Należy jednak dodać, że badania z Rumunii i Węgier ${ }^{42}$ doprowadziły do wniosków przeciwnych.

Podsumowując, można stwierdzić, że dane z systemu ELA potwierdzaja teorię filtra, wskazująca, że nierówność we wchodzeniu na rynek pracy jest skutkiem jakości kapitału ludzkiego, a składają się na niego zarówno wyższe wykształcenie, jak i doświadczenie zawodowe. Dane te potwierdzaja także teorie sygnałów i konkurencji, gdyż dzięki pracy zawodowej podczas studiów (a także przed rekrutacją na studia) absolwenci szybciej adaptują się do oczekiwań pracodawcy. Dzięki temu pracodawcy ponoszą także niższe koszty wdrożenia do pracy. Trzeba dodać, że art. 62 ustawy Prawo o szkolnictwie wyższym z 2018 r. daje uczelniom możliwość prowadzenia studiów dualnych, jako studiów o profilu praktycznym z udziałem pracodawcy, ale system ELA nie wyodrębnia takiego rodzaju studiów. Należy oczekiwać, że jego twórcy uzupełnią dane w tym zakresie w kolejnych pomiarach.

Kolejne edycje systemu ELA $^{43}$ pozwola także na porównanie ekonomicznych losów absolwentów dla następnych ich roczników i dla kolejnych lat pracy po uzyskaniu dyplomu dla rocznika 2018. Interesujące będzie także pogłębione badanie weryfikowanej w tym opracowaniu hipotezy badawczej dla wybranych kierunków studiów.

Allen, J., van der Velden, R. (2009). Competencies and Early Labour Market Careers of Higher Education Graduates. Higher Education as Generator of Strategic Competences (HEGE$\mathrm{SCO})$.

Andrews, J., Higson, H. (2010). Graduate employability, 'soft skills' versusu 'hard' business knowledge: a European study. Higher Education in 2010. 33(4): 411-422.

Apanowicz, J. (2002). Metodologia ogólna. Gdynia: Wyższa Szkoła Administracji i Biznesu.

Arrow, K. (1973). Higher education as a filter. Journal of Public Economics 2(3): 193-216.

Brown, P., Hesketh, A., Williams, A. (2002). Employability in a knowledge-driven economy. School of Social Sciences. Cardiff University, Working Paper Series, Paper 26: 1-39.

Czubak-Koch, M., Monteagudo, J.G., Nizińska, A., Padilla-Carmona, T. (2017) Między uniwersytetem a światem pracy. Tranzycje w narracjach studentów polskich i hiszpańskich. Dyskursy Młodych Andragogów 18.

Dziechciarz-Duda, M., Przybysz, K. (2014), Wykształcenie a potrzeby rynku pracy. Klasyfikacja absolwentów wyższych uczelni. Prace Naukowe Uniwersytetu Ekonomicznego we Wrocławiu 327: 303-312.

Grobelna, A. (2016). Doświadczenie pracy i jego znaczenie dla kształtowania postaw przyszłych kadr obsługi ruchu turystycznego. Ekonomiczne Problemy Turystyki 2(34): 343-359.

Hesketh, A.J. (2000). Recruiting an Elite? Employers' perception of graduate education and training. Journal of Education and Work 13(3): 245-271.

Jarecki, W. (2010) Praca i dochody studentów. Polityka Społeczna 1: 21-25.

41 Por. Rocki (2021): 90.

42 Săveanu, Ştefanescu (2019).

43 Obecnie dostępne są raporty ELA dla absolwentów rocznika 2019. 
Kosi, T., Nastav, B., Sustersic, J. (2013). Does student employment deteriorate academic performance? The case of Slovenia. Revija Za Socijalnu Politiku 20(3): 253-274.

Kryńska, E. (1995). Podział rynku pracy. Koncepcje segmentacyjne. Acta Universitatis Lodzensis. Folia Oeconomica 137: 15-30.

Lindberg, M.E. (2008). Higher education-to-work transitions in the knowledge society: the initial transition and positional competition point of view. Higher Education in Europe 33: 375-385.

Marszałek, A. (2012). 'Zatrudnialność' - nowa i poszukiwana cecha pracownika. Polityka Społeczna 11/12: 20-23.

Materiały informacyjne na temat zasobów udostępnianych w ramach szóstej edycji ogólnopolskiego systemu monitorowania Ekonomicznych Losów Absolwentów szkół wyższych (ELA). $<$ https://ela.nauka.gov.pl/pl/experts/source-data> [dostęp: 27.08.2021].

Okay-Somerville, B., Scholarios, D. (2015). Między studiami a pracą - samodzielne zarządzanie kariera, zatrudnialność, sukces zawodowy. Spojrzenie na teorię kariery z perspektywy społeczno-kognitywnej. Zarządzanie Zasobami Ludzkimi 6(107): 33-60.

Ostoj, I. (2016). Motywy podejmowania pracy przez studentów studiów stacjonarnych - wyniki badań. Studia i Prace WNEiZ Uniwersytetu Szczecińskiego 44/1.

Ostoj, I. (2018). Reasons full-time students of economics in Poland undertake jobs. Managerial Economics 19(1): 117-131.

Ostoj, I. (2019). The significance of motivations and selected effects of student employment in the course of studies: a case of an economics study program in Poland. European Journal of Educational Research 9(1): 165-177.

Piróg, D. (2013a). Wybrane determinanty tranzycji absolwentów studiów wyższych na rynek pracy. Studia Ekonomiczne 160: 131-138.

Piróg, D. (2013b). Wybrane teorie przechodzenia absolwentów szkół wyższych na rynek pracy w warunkach gospodarki opartej na wiedzy. Prace Komisji Geografii Przemysłu Polskiego Towarzystwa Geograficznego 23: 146-159.

Raport (2012). Raport z badań w II edycji projektu Uczelnia Przyjazna Pracodawcom. Warszawa: Instytut Pracy i Spraw Socjalnych.

Richardson, M., Evans, C., Gbadamosi, G. (2009). Funding full-time study through part-time work. Journal of Education and Work 22(4): 319-334.

Rocki, M. (2018). Czy nowe kierunki studiów są dowodem na innowacyjność szkół wyższych? E-Mentor 3: 14-21.

Rocki, M. (2019). Ranking polskich uczelni według ekonomicznych losów absolwentów. Ekonomista 3: 343-354.

Rocki, M. (2020). Absolwenci studiów ekonomicznych na rynku pracy - analiza na przykładzie rocznika 2014. Ekonomista 6: 837-861.

Rocki, M. (2021). Próba rankingu uczelni kształcacych na kierunku prawo na podstawie oceny sytuacji ich absolwentów na rynku pracy. E-Mentor 2: 88-94.

Rocki, M., Werner, A. (2021). Absolwenci prawa rocznika 2018 na rynku pracy. E-Mentor 4: 4-15.

Săveanu, S., Ştefanescu, F. (2012). Academics perception about university curricula in Bologna System: case study at the University of Oradea, Romania, [w:] G. Pusztai, A. Hatos, T. Cegledi (eds.), Third Mission of Higher Educationin a Cross-Border Region. Center for Higher Education Research and Development - Hungary (CHERD-Hungary). University of Debrecen: 96-113.

Săveanu, S., Ştefanescu, F. (2019). Working or learning? Working students in the Romanian-Hungarian cross-border area. Revista Romaneasca pentru Educatie Multidimensionala 11: $248-277$.

Spence, M. (1973). Job market signaling. The Quarterly Journal of Economics 87(3): 355-374.

Teichler, U. (2002), Graduate employment and work in Europe: diverse situations and common perceptions. Tertiary Education and Management 8: 199-216.

Zając, T., Jasiński, M., Bożykowski, M. (2017). Does it pay to be a STEAM Graduate? Evidence from the Polish Graduate Tracking System. Research\&Occasional Paper Series. Center for Studies in Higher Education. University of California. Berkeley.

Zając, T., Jasiński, M., Bożykowski, M. (2018). Early careers of tertiary graduates in Poland: employability, earnings, and differences between public and private higher education. Polish Sociological Review 202(2): 187-208. 


\section{COMBINING STUDIES WITH PAID WORK AND THE ENTRY OF HIGHER EDUCATION GRADUATES TO THE LABOUR MARKET}

\section{Sum mary}

The study uses data from the national system of monitoring the economic fate of graduates who obtained their diplomas in 2018. The results confirm the opinions on the positive role of work experience. The differences in the fate of graduates of various groups of graduates were indicated, distinguishing the degrees and modes of study and the fields of study to which the majors are assigned. Relative unemployment experience for people without work experience is almost twice as high as for people with such experience, and the average wages are about $35 \%$ lower. At the same time, the study indicates exceptions to the rule in question.

Keywords: universities; graduates; job market; unemployment; wages; JEL codes: I21J23, J29 
